\title{
UJI PERFORMANSI RICE TRANSPLANTER TIPE WALKING MODEL PF48 (2 ZS-4A) DI DESA TANJUNG KECAMATAN TANJUNG KABUPATEN LOMBOK UTARA-NTB
}

\author{
Performance Test of Walking Type Rice Transplanter PF48 (2 ZS-4A) Model in \\ Tanjung Village, Tanjung Subdistrict, North Lombok Regency-NTB
}

\author{
Ni Luh Tri Dewi Lestari' ${ }^{1}$, Murad ${ }^{1}$, Asih Priyati ${ }^{1}$ \\ ${ }^{1}$ Program Studi Teknik Pertanian, Fakultas Teknologi Pangan dan Agroindustri, \\ Universitas Mataram \\ Email ${ }^{*}$ : mu_rad08@yahoo.com
}

Diterima: 3 Mei 2017

Disetujui: 15 Agustus 2017

\begin{abstract}
In order to improve the performance of workers and crops, especially rice, the government provides agricultural technology, in the form of rice transplanter machine, to groups of farmer in Tanjung Village, Tanjung Subdistrict, North Lombok Regency. Rice transplanter is a machine used to distribute the plant rice evenly. In this research, the performance of walking type rice transplanter machine PF48 (2 ZS-4A) model was carried out on rice field in Tanjung Village, Tanjung Subdistrict, North Lombok Regency, with the aim to conduct performance testand to determine effectiveness and efficiency of the rice transplanter machine, at various area of paddy fields andvarious planting systems. Method used was experimental by conducting on field research. Research parameters consist of land condition during planting, crops condition, planting line distance, number of clumps per hole, depth of planting, total planting time, tool speed, effective field capacity, theoretical field capacity, and field efficiency. Data analysis in this research were conducted from the measurement at the beginning of the operation of rice transplanter machine on different area, i.e. the smallest $\left(400 \mathrm{~m}^{2}\right)$, moderate $\left(700 \mathrm{~m}^{2}\right)$, and the biggest $\left(1,000 \mathrm{~m}^{2}\right)$, and using different planting system (elongated and shortened). In the terms of area, this study showed field efficiency on the largest plot $\left(1,000 \mathrm{~m}^{2}\right)$ is more efficient (83\%) compared to other plots. Whereas field efficiency based on planting system showed that the elongated system is more efficient than shortened system. The field efficiency obtained on the elongated system is above 50\%, i.e. $68 \%$ for the smallest area, 75\% for moderate area, and $83 \%$ for the largest one. While the efficiency on the shortened system is $24 \%$ for the smallest area, $35 \%$ for moderate area, and $45 \%$ for the largest area.
\end{abstract}

Keywords: effectiveness, efficiency, rice transplanter, planting system, rice plan

\begin{abstract}
ABSTRAK
Dalam meningkatkan kinerja pekerja dan hasil panen khususnya padi, pemerintah memberikan teknologi pertanian berupa mesin rice transplanter kepada kelompok tani di Desa Tanjung, Kecamatan Tanjung, Kabupaten Lombok Utara. Mesin rice transplanter merupakan mesin yang digunakan untuk menanam padi secara merata. Pada penelitian
\end{abstract}


ini dilakukan uji performansi mesin rice transplanter tipe walking model PF48 (2 ZS-4A) pada lahan persawahan di Desa Tanjung Kecamatan Tanjung Kabupaten Lombok Utara dengan tujuan untuk melakukan uji performansi mesin rice transplanter serta mengetahui efektivitas dan efisiensi mesin rice transplanter terhadap berbagai luas petakan sawah dan sistem tanam. Metode yang digunakan adalah eksperimental dengan penelitian dilakukan dilapangan. Parameter penelitian dari kondisi lahan saat penanaman, keadaan hasil tanam, jarak baris tanam, jumlah rumpun per lubang, kedalaman tanam, total waktu tanam, kecepatan maju alat, kapasitas lapang efektif, kapasitas lapang teoritis dan efisiensi lapang. Analisis data pada penelitian ini adalah pengukuran dari awal pengoperasian mesin rice transplanter pada luasan yang berbeda, yaitu terkecil $\left(400 \mathrm{~m}^{2}\right)$, sedang $\left(700 \mathrm{~m}^{2}\right)$ dan terbesar $\left(1.000 \mathrm{~m}^{2}\right)$ serta penggunaan sistem tanam yang berbeda (memanjang dan memendek) pada setiap petakan. Pada penelitian ini, dari segi luasan, efisiensi lapang pada petakan terbesar $\left(1.000 \mathrm{~m}^{2}\right)$ lebih efisien $(83 \%)$ dibandingkan dengan petakan lainnya. Sedangkan, efisiensi lapang berdasarkan sistem tanam lebih efisien dengan menggunakan sistem memanjang dibandingkan dengan sistem memendek. Di mana efisiensi lapang yang didapatkan pada sistem memanjang di atas 50\%, yaitu $68 \%$ untuk luasan terkecil, $75 \%$ untuk luasan sedang, dan $83 \%$ untuk luasan terbesar. Sedangkan pada sistem memendek, didapatkan efisiensi $24 \%$ untuk luasan terkecil, $35 \%$ untuk luasan sedang dan $45 \%$ untuk luasan terbesar.

Kata kunci: efektivitas, efisiensi, rice transplanter, sistem tanam, tanaman padi

\section{PENDAHULUAN}

Perkembangan

penggunaan teknologi pertanian sangat pesat dalam upaya meningkatkan kualitas dan kuantitas produksi seiring dengan kemajuan ilmu pengetahuan dan teknologi untuk memenuhi bahan pangan sebagai salah satu kebutuhan pokok hidup manusia yang terus bertambah. Penerapan teknologi pertanianbaik dalam kegiatan pra panen maupun pasca panen, menjadi penentu dalam mencapai kecukupan pangan baik kuantitas maupun kualitas produksi. Teknologi pertanian telah berperan untuk meningkatkan efisiensi dan produktivitas usaha tani komoditas pangan di negara-negara maju dan negaranegara berkembang termasuk Indonesia, khususnya di Nusa Tenggara Barat, Desa Tanjung Kecamatan Tanjung Kabupaten Lombok Utara.

Nusa Tenggara Barat adalah salah satu provinsi di Indonesia yang berada dalam gugusan Sunda Kecil dan termasuk dalam Kepulauan Nusa Tenggara. Provinsi yang biasa disingkat NTB ini memiliki 10 Kabupaten/Kota, seperti
Kabupaten Lombok Utara. Karakteristik pembangunan sumber daya manusia di Kabupaten Lombok Utara dilaksanakan melalui pengendalian pertumbuhan penduduk dan pengembangan kualitas penduduk melalui perwujudan keluarga kecil yang berkualitas melalui pengembangan investasi sosial di bidang pendidikan, pemberdayaan dan kesehatan masyarakat (Anonim $\left.{ }^{2}, 2015\right)$.

Di Desa Tanjung Kecamatan Tanjung biasanya penduduknya berprofesi sebagai petani (Anonim ${ }^{2}, 2015$ ). Di mana petani tersebut lebih banyak menanam padi dibandingkan dengan tanaman yang lainnya. Padi adalah tanaman yang paling penting di negeri kita di Indonesia ini. Dikarenakan padi merupakan makanan pokok di Indonesia berupa nasi dari beras yang tentunya dihasilkan oleh tanaman padi. Sehingga untuk meningkatkan kinerja pekerja dan hasil panen khususnya padi, pemerintah memberikan teknologi pertanian berupa mesin rice transplanter kepada kelompok tani di Desa Tanjung Kecamatan Tanjung. Mesin rice transplanter merupakan mesin yang digunakan untuk menanam padi. 
Penggunaan mesin tanam bibit padi rice transplanter diharapkan dapat membuat pekerjaan petani semakin mudah, mempercepat waktu tanam bibit padi dan meningkatkan produktivitas kerja petani (Sandra, 1995). Mesin yang diberikan oleh pemerintah di Desa Tanjung Kecamatan Tanjung Kabupaten Lombok Utara adalah mesin rice transplanter bermerk maxxi tipe walking model PF48 (2 ZS-4A). Pemerintah memberikan bantuan mesin kepada beberapa daerah, khususnya Kabupaten Lombok Utara. Pemerintah memberikan mesin rice transplanter kepada setiap kabupaten dengan merk yang berbeda. Pembagian mesin rice transplanter ini tidak diberikan berdasarkan kajian topografi dan geografis dari tiap kabupaten. Sehingga perlu dilakukan pengujian tentang efektif atau efisiensi dari mesin yang diberikan pemerintah tersebut (Anonim ${ }^{1}$, 2015).

Di Desa Tanjung Kecamatan Tanjung memiliki luas dan bentuk petakan sawah yang bervariasi (Anonim ${ }^{1}, 2015$ ). Di mana penanaman padi yang dilakukan di Desa Tanjung masih menggunakan penanaman manual, sehingga ketika mesin rice transplanter mulai diterapkan sejak lima tahun terakhir para petani masih belum terlalu menguasai cara penggunaan mesin rice transplanter tersebut (Anonim $\left.{ }^{1}, 2015\right)$. Oleh karena itu, untuk mengetahui performansi mesin rice transplanter serta efektifitas dan efisiensi mesin tersebut terhadap luasan dan sistem tanam yang berbeda, maka dilakukan penelitian "Uji Performansi Rice transplanter Tipe Walking Model PF48 (2 ZS-4A) di Wilayah Desa Tanjung Kecamatan Tanjung Kabupaten Lombok Utara-NTB".

\section{METODE PENELITIAN}

\section{Alat dan Bahan}

Adapun alat-alat yang digunakan dalam penelitian ini adalah rice transplanter, nampan, ember besar, karung beras berukuran besar, jerami kering, patok kayu, tali rapia, meteran, gunting, stopwatch dan perlengkapan alat tulis. Adapun bahan yang digunakan dalam penelitian ini adalah bensin dan benih atau bibit padi.

\section{Metode Penelitian}

Metode yang digunakan dalam penelitian ini adalah metode eksperimental yang dilaksanakan di lahan persawahan. Metode eksperimental merupakan metode yang dilakukan dengan mengadakan manipulasi terhadap objek dan adanya suatu kontrol. Tujuan metode eksperimental adalah untuk menyelidiki ada tidaknya hubungan sebab akibat dan berapa besar hubungan sebab akibat tersebut dengan cara memberikan perlakuan-perlakuan tertentu dan menyediakan kontrol untuk perbandingan (Siregar, 2009).

Dalam penelitian ini teknik pengambilan sampel yang digunakan adalah dengan cara simple random sampling (penarikan sampel secara acak sederhana). Di dalam sampel acak setiap petani di Desa Tanjung memiliki kemungkinan yang sama untuk menjadi anggota sampel. Adapun sampel yang digunakan dalam penelitian ini adalah sampel wilayah. Area sampling atau sampel wilayah dipakai ketika peneliti dihadapkan pada situasi bahwa populasi penelitiannya tersebar di berbagai wilayah (Siregar, 2009).

Daerah yang diambil dalam penelitian ini adalah Desa Tanjung, Kecamatan Tanjung yang memiliki lahan pertanian sawah. Data tentang luas lahan pertanian di Desa Tanjung dapat dilihat pada Tabel 1. Sampel penduduk dalam penelitian ini adalah petani yang terdapat di Dusun Lading-lading, Dusun Kr. Bangket, Dusun Kr. Panasan dan Dusun Kandang Kaoq yang berjumlah 453 petani. 
Tabel 1. Luas Lahan Pertanian dan Jumlah Petani di Desa Tanjung

\begin{tabular}{|c|c|c|c|}
\hline No. & Dusun & $\begin{array}{c}\text { Luas } \\
\text { Lahan } \\
(\mathrm{Ha})\end{array}$ & $\begin{array}{c}\text { Jumlah } \\
\text { Petani } \\
\end{array}$ \\
\hline 1 & $\begin{array}{l}\text { Lading- } \\
\text { lading }\end{array}$ & 128,85 & 258 \\
\hline 2 & $\begin{array}{c}\text { Kr. } \\
\text { Bangket }\end{array}$ & 25,15 & 44 \\
\hline 3 & $\begin{array}{c}\text { Kr. } \\
\text { Panasan }\end{array}$ & 20,15 & 35 \\
\hline 4 & $\begin{array}{c}\text { Kandang } \\
\text { Kaoq }\end{array}$ & 46,85 & 116 \\
\hline \multicolumn{2}{|c|}{ Jumlah } & 221 & 453 \\
\hline
\end{tabular}

Sumber: BPP, 2015.

Dalam perhitungan jumlah sampel akan menggunakan rumus sebagai berikut:

$\mathrm{n}=\frac{\mathrm{N}}{1+\mathrm{Ne}^{2}}$

Keterangan:

$\mathrm{n}=$ Ukuran sampel.

$\mathrm{N}=$ Ukuran populasi.

$\mathrm{e}=$ Tingkat kesalahan yang masih bisa ditolerir (10\%) dan tingkat kepercayaan $(90 \%)$.

Dari jumlah petani empat dusun tersebut dan tingkat kesalahan sebesar $10 \%$ maka dengan rumus diatas diperoleh sampel sebagai berikut:

$$
\mathrm{n}=\frac{453}{1+453(10 \%)^{2}}=\frac{453}{1+453(0,1)^{2}}=82 \text { petani }
$$

Berdasarkan perhitungan dengan rumus di atas, dapat disimpulkan bahwa jumlah sampel yang akan diambil dari petani di Desa Tanjung adalah 82 petani. Untuk pembagian tiap dusun di Desa Tanjung, digunakan perhitungan sebagai berikut:

1. Lading-lading $=\frac{258}{453} \times 82=47$ petani.

2. Kr. Bangket $=\frac{44}{453} \times 82=8$ petani.

3. Kr. Panasan $=\frac{35}{453} \times 82=6$ petani.

4. Kandang Kaoq $=\frac{116}{453} \times 82=21$ petani.
Setelah didapatkan jumlah sampel yang digunakan sebanyak 82 sampel, maka selanjutnya dilakukan survey lapangan dengan mengukur luas petakan tiap anggota sampel menggunakan roll meter. Di mana pengukuran dilakukan pada 3 luas petakan, yakni petakan terbesar, petakan sedang dan petakan terkecil. Sehingga sampel petakan yang digunakan sebanyak 166 petakan dengan ukuran yang berbeda (terbesar, sedang dan terkecil).

Setelah survey luas petakan didapatkan, kemudian data diolah dengan menggunakan metode statistik, yakni median dengan menggunakan excel. Median menentukan letak data setelah data itu disusun menurut urutan nilainya. Median adalah nilai yang berada ditengahtengah data setelah diurutkan dari yang terkecil sampai terbesar. Median cocok digunakan bila data yang kita miliki tidak menyebar normal atau memiliki nilai yang berbeda-beda secara signifikan. Sistem tanam yang digunakan dalam penelitian ini menggunakan dua macam arah, yakni arah memanjang (4:1:4) dan arah memendek (4:1:4). Jarak tanam antar baris $30 \mathrm{~cm}$ dengan jarak lajur antar baris tanam $30 \mathrm{~cm}$. Sistem tanam (4:1:4) ini, dapat dilihat pada gambar di bawah.

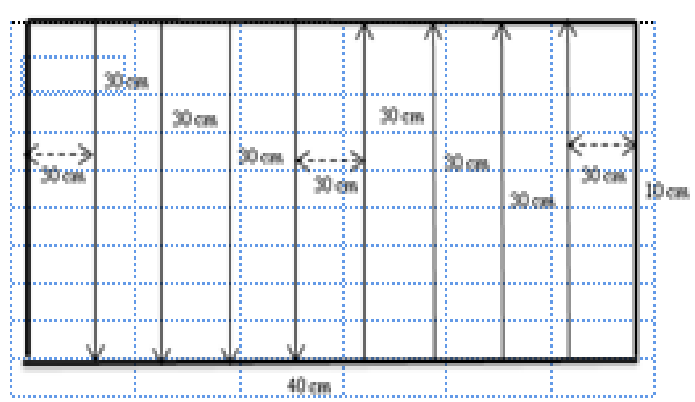

Gambar 1. Sistem Tanam Memendek $(4: 1: 4)$ 


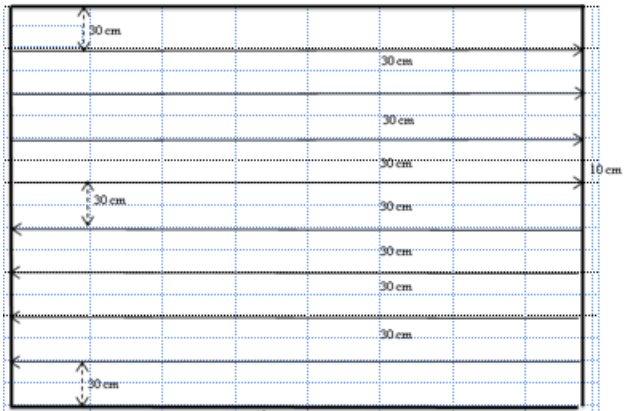

Gambar 2. Sistem Tanam Memanjang $(4: 1: 4)$

Pada penelitian ini digunakan luas petakan dan bentuk lahan yang berbedabeda, yakni sesuai dengan survey yang dilakukan dengan luas lahan ukuran minimum $400 \mathrm{~m}^{2}$, sedang $700 \mathrm{~m}^{2}$ dan maksimal $1.000 \mathrm{~m}^{2}$ yang berbentuk persegi panjang. Pada luas lahan dengan ukuran minimum, sedang dan maksimal yang berbentuk persegi panjang, sistem tanam yang digunakan memanjang dan memendek.

\section{Prosedur Penelitian}

Dalam penelitian ini ada beberapa langkah yang perlu dilakukan antara lain:

1. Mempersiapkan alat dan bahan.

2. Melakukan penelitian pendahuluan untuk mengetahui kondisi alat yang digunakan.

3. Melakukan persemaian padi sebelum melakukan penanaman selama 15 hari, di mana cara persemaian dengan menggunakan:

a. Merendam benih atau bibit padi sebanyak $25 \quad \mathrm{~kg}$ dengan menggunakan ember besar yang berisi air selama 24 jam.

b. Meniriskan benih atau bibit padi dengan menggunakan karung beras dan diletakkan di tempat berangin sedang selama 24 jam.

c. Selagi penirisan dilakukan, nampan yang berukuran $60 \mathrm{~cm} \times$ $30 \mathrm{~cm}$ di berikan tanah halus dan tanah kompos dengan perbandingan $2: 1$ sedalam $1 \mathrm{~cm}$. Nampan ini didapatkan dari mesin rice transplanter sebanyak 150 nampan, namun untuk penelitian ini digunakan 195 nampan. Di mana 150 nampan dapat menanam satu hektar lahan.

d. Setelah proses penirisan selesai, kemudian benih atau bibit padi disebar pada tiap nampan dengan takaran setengah gelas air mineral atau sekitar 125 gram bibit atau benih padi.

e. Benih atau bibit yang disebar secara merata kemudian diletakkan secara berurutan dan ditumpuk dengan tumpukan jerami hingga benih atau bibit padi tak terlihat.

f. Melakukan pemberian air secukupnya setiap pagi dan sore hari dengan menggunakan gembor selama 15 hari.

4. Mengukur luas lahan dan membuat petakan sesuai ukuran yang ditentukan.

5. Meletakkan patok kayu pada tiap sudut lahan buatan dan melingkarinya dengan tali rapia.

6. Mengoperasikan rice transplanter dengan pengaturan 3 helai bibit atau benih padi pada tiap lubang mesin tanam.

7. Mengukur waktu tanam/lintasan, waktu tanam/perluasan, waktu belok, waktu pemasukan padi, lebar jarak efektif, jarak antar lajur, banyaknya lajur tanaman/lintasan dan total waktu tanam.

\section{Parameter Penelitian}

Parameter yang diamati dalam uji performansi rice transplanter tipe walking model PF48 (2 ZS-4A) di Desa Tanjung Kecamatan Tanjung Kabupaten Lombok Utara-NTB, antara lain:

1. Kondisi lahan saat penanaman

2. Keadaan hasil tertanam

3. Jarak baris tanam

4. Jumlah rumpun per lubang

5. Kedalaman tanam

6. Total waktu tanam 
7. Kecepatan maju alat

8. Kapasitas lapang efektif

$\mathrm{Ke}=\mathrm{A} / \mathrm{t}$

Dimana:

$\mathrm{Ke}=$ Kapasitas lapang efektif $\left(\mathrm{m}^{2} / \mathrm{det}\right)$

$\mathrm{A}=$ Luas areal atau bidang tanah $\left(\mathrm{m}^{2}\right)$

$\mathrm{t}=$ Waktu kerja alat (detik)

9. Kapasitas lapang teoritis

$\mathrm{Kt}=\mathrm{V} \times \mathrm{W}$

Dimana:

$\mathrm{Kt}=$ Kapasitas lapang teoritis

$\left(\mathrm{m}^{2} / \mathrm{det}\right)$

$\mathrm{V}=$ Kecepatan maju alat $(\mathrm{m} / \mathrm{det})$

$\mathrm{W}=$ Lebar jarak efektif

10. Efisiensi lapang

$\mathrm{El}=\frac{\mathrm{K}_{\text {efektif }}}{\mathrm{K}_{\text {teoritis }}} \times 100 \%$

Dimana:

$\mathrm{El}=$ Efisiensi lapang (ha/jam)

$\mathrm{K}=$ Kapasitas lapang (ha/jam)

\section{Analisis Data}

Analisis data yang dilakukan adalah dengan pendekatan matematis untuk menyelesaikan model perhitugan matematik.

\section{HASIL DAN PEMBAHASAN}

\section{Karakteristik Wilayah}

Kabupaten Lombok Utara terbentuk dengan disahkannya Undang-undang Republik Indonesia Nomor 26 Tahun 2008 tentang Pembentukan Kabupaten Lombok Utara di Provinsi Nusa Tenggara Barat. Pemekaran ini terjadi karena mempertimbangkan bahwa Kabupaten Lombok Barat yang mempunyai luas wilayah $\pm 1.672,81 \mathrm{~km}^{2}$ dengan penduduk pada tahun 2007 yang berjumlah 739.725 jiwa dan terdiri atas 15 kecamatan. Kondisi demikian perlu diatasi dengan memperpendek rentang kendali pemerintahan melalui pembentukan daerah otonom baru sehingga pelayanan publik dapat ditingkatkan guna mempercepat terwujudnya kesejahteraan masyarakat (Anonim $\left.{ }^{2}, 2015\right)$.

Dengan diterbitkannya UndangUndang, Nomor 26 Tahun 2008 tentang pembentukan Kabupaten Lombok Utara, dilanjutkan dengan peresmian dan pelantikan Pejabat Bupati Lombok Utara pada tanggal 30 Desember 2008, menjadikan Kabupaten Lombok Utara sebagai Daerah Otonomi baru di Provinsi Nusa Tenggara Barat.Kabupaten Lombok Utara menjadi salah satu dari sepuluh Kabupaten atau Kota di Provinsi Nusa Tenggara Barat.

Kabupaten Lombok Utara mempunyai luas wilayah daratan yakni seluas 809,53 $\mathrm{km}^{2}$ dan secara administrastif terbagi dalam 5 Kecamatan, 33 Desa dan 322 Dusun, yang mana Kecamatan Bayan memiliki luas wilayah terbesar dengan luas wilayah 329,10 $\mathrm{km}^{2}$ dan terkecil adalah Kecamatan Pemenang dengan luas wilayah 81,09 $\mathrm{km}^{2}$.Karakteristik pembangunan sumber daya manusia di Kabupaten Lombok Utara dilaksanakan melalui pengendalian pertumbuhan penduduk dan pengembangan kualitas penduduk melalui perwujudan keluarga kecil yang berkualitas melalui pengembangan investasi sosial dibidang pendidikan, pemberdayaan dan kesehatan masyarakat (Anonim ${ }^{2}$, 2015).

Tabel 2. Luas Lahan Pertanian dan

\begin{tabular}{cccc}
\multicolumn{4}{c}{ Jumlah Petani di Desa Tanjung } \\
\hline \multirow{2}{*}{ No. } & Dusun & $\begin{array}{c}\text { Luas Lahan } \\
\text { (Ha) }\end{array}$ & $\begin{array}{c}\text { Jumlah } \\
\text { Petani }\end{array}$ \\
\hline 1 & Lading-lading & 128,85 & 258 \\
2 & Kr. Bangket & 25,15 & 44 \\
3 & Kr. Panasan & 20,15 & 35 \\
4 & Kandang & 46,85 & 116 \\
\hline & Kaoq & 221 & 453 \\
\hline
\end{tabular}

Sumber: BPP, 2015.

Pada tahun 2008 penduduk Kabupaten Lombok Utara berjumlah sekitar 207.998. Dari jumlah tersebut 76\% di antaranya adalah penduduk usia kerja 
(usia 15-64 tahun), maka dari segi jumlah usia produktif, sumber daya manusia Kabupaten Lombok Utara cukup memiliki peluang untuk lebih berkembang (Anonim $\left.{ }^{2}, 2015\right)$.

Di Desa Tanjung Kecamatan Tanjung biasanya penduduknya berprofesi sebagai petani, di mana petani tersebut lebih banyak menanam padi dibandingkan dengan tanaman yang lainnya(Anonim², 2015). Padi adalah tanaman yang paling penting di negeri kita di Indonesia ini. Dikarenakan padi merupakan makanan pokok di Indonesia berupa nasi dari beras yang tentunya dihasilkan oleh tanaman padi. Sehingga untuk meningkatkan kinerja pekerja dan hasil panen khususnya padi, pemerintah memberikan teknologi pertanian berupa mesin rice transplanter kepada para petani (Sandra, 1995).

\section{Keadaan Lahan}

Tanah areal penelitian merupakan lahan asli dan lahan urug yang dipadatkan. Pengolahan tanah dilakukan pada lahan yang telah disediakan dengan luas sebesar $4.200 \mathrm{~m}^{2}$. Di mana pada lahan tersebut direkayasa dengan membuat ukuran pada petakan terkecil $400 \mathrm{~m}^{2}$ terbagi menjadi 10 $\mathrm{m} \times 40 \mathrm{~m}$, petakan sedang $700 \mathrm{~m}^{2}$ dengan ukuran $13,23 \mathrm{~m} \times 52,92 \mathrm{~m}$ dan petakan terbesar $1.000 \mathrm{~m}^{2}$ terbagi menjadi $15,81 \mathrm{~m}$ $\times$ 63,24 m. Pengolahan tanah ke-tiga petakan tersebut dilakukan dengan menggunakan traktor roda dua. Di mana hasil yang didapatkan pada kedalaman olah ke tiga petakan tersebut, mencapai kedalaman 23,4 cm.

Alat tanam tipe walking tersebut dilengkapi dengan pelampung, sehingga meskipun pengolahan tanah cukup dalam (mencapai $40 \mathrm{~cm}$ ) tidak mengakibatkan alat tanam tenggelam. Pelampung terdapat pada tiga bagian yaitu kiri, kanan dan tengah. Pelampung kiri dan kanan berukuran sama, yaitu $68 \mathrm{~cm} \times 38,8 \mathrm{~cm}$ dan bagian tengah berukuran $75,2 \mathrm{~cm} \times$ $35,4 \mathrm{~cm}$.

\section{Penanaman}

Penanaman dilakukan pada saat bibit berumur sekitar 15 hari (Sandra, 1995), dengan menggunakan alat tanam padi (rice transplanter) tipe walking merk maxxi, dapat dilihat pada Tabel 5.

Tabel 3. Hasil Kerja Mesin Rice transplanter

\begin{tabular}{ll}
\hline Nama produk & Rice transplanter 2 ZS-4A \\
\hline $\begin{array}{l}\text { Dimensi mesin } \\
\text { Kapasitas }\end{array}$ & $214 \mathrm{~cm} \times 150 \mathrm{~cm} \times 87 \mathrm{~cm}$ \\
Tangki & \\
Daya & $4,3 \mathrm{HP}$ pada $3.200 \mathrm{rpm}$ \\
0,42 hektar & 3,8 Liter \\
1,26 hektar & 10,4 Liter \\
\hline
\end{tabular}

Sistem penanaman yang dilakukan dengan menggunakan sistem memendek dan memanjang. Dimana ke dua sistem dibagi menjadi tiga luasan yang berbeda (terkecil, sedang dan terbesar). Pengoperasian penanaman dapat dimulai setelah tuas kopling digerakkan ke posisi "ON". Kemudian menentukan jumlah rumpun yang tertanam dengan menekan tuas yang berada di samping tuas kopling. Menentukan kedalaman tanam yang digunakan dengan menarik atau menurunkan tuas yang ada di samping tuas gerak. Setelah itu, tarik tuas gerak dan kemudian tarik tuas tanam. Posisi tuas dapat di lihat pada gambar mesin rice transplanter.

\section{a. Mekanisme Mesin Rice Transplanter}

Mekanisme kerja alat tanam padi tersebut adalah sebagai berikut, sumber tenaga berasal dari motor bensin. Energi dari engine digunakan untuk menggerakkan poros melalui kopel, putaran poros dihubungkan dengan dua macam gear. Gear pertama digunakan untuk menjalankan papan benih yang bergerak kiri-kanan. Sedangkan, gear yang kedua digunakan untuk memutar jari-jari tanam dari sprocket yang dihubungkan dengan rantai.

Jari-jari tanam akan menjepit bibit yang tersedia di papan benih. Papan benih 
bergerak secara lateral sesuai dengan perputaran jari-jari tanam (Kohnosuke, 1992). Gerakan papan benih diatur oleh mekanisme gigi ratchet. Gigi ratchet digunakan untuk mekanisme pengunci sewaktu menahan suatu beban. Kualitas hasil penanaman yang diamati, yakni hasil tertanam, jarak tanam, jumlah rumpun per lubang, kedalaman tanam dan efisiensi lapang.

\section{b. Hasil Tertanam}

Banyaknya bibit yang tertanam berpengaruh pada kerapatan tanaman padi. Kerapatan tanaman akan mempengaruhi hasil akhir, yaitu panen. Dari hasil pengujian diperoleh bahwa jumlah baris yang tertanam dengan sistem memanjang adalah petakan kecil dengan 8 lintasan menghasilkan jumlah baris tertanam 32 baris. Petakan sedang dengan 11 lintasan menghasilkan jumlah baris 44 baris. Sedangkan, petakan terbesar dengan 13 lintasan menghasilkan jumlah baris 52 baris. Jumlah baris yang tertanam dengan sistem memendek adalah petakan kecil dengan 33 lintasan menghasilkan jumlah baris tertanam 132 baris. Petakan sedang dengan 44 lintasan menghasilkan jumlah baris 176 baris. Sedangkan, petakan terbesar dengan 52 lintasan menghasilkan jumlah baris 208 baris.

Tabel 4. Hasil Kerja Penanaman Mesin Rice transplanter

\begin{tabular}{ccccc}
\hline Sistem & $\begin{array}{c}\text { Luasan } \\
\left(\mathrm{m}^{2}\right)\end{array}$ & $\begin{array}{c}\text { Ukuran } \\
(\mathrm{P} \times \mathrm{L}) \\
(\mathrm{m})\end{array}$ & $\begin{array}{c}\text { Lebar } \\
\text { kerja } \\
\text { alat } \\
(\mathrm{m})\end{array}$ & $\begin{array}{c}\text { Jumlah } \\
\text { Lintasan }\end{array}$ \\
\hline \multirow{3}{*}{ Memanjang } & $400(10 \times 40)$ & 1,20 & 8 \\
& $1.000(13,23 \times 52,92)$ & 1,20 & 11 \\
\hline \multirow{3}{*}{ Memendek } & $400(10 \times 63,24)$ & 1,20 & 13 \\
\hline & $700(13,23 \times 52,92)$ & 1,20 & 33 \\
& $1.000(15,81 \times 63,24)$ & 1,20 & 44 \\
\hline
\end{tabular}

Keadaan baris tertanam dari hasil tersebut dibedakan menjadi dua bagian, yaitu tertanam dalam keadaan baik (posisi bibit $30-90^{\circ}$ ) dan tertanam dalam keadaan kurang baik (posisi bibit 0-30 ) (Sandra, 1995). Pada ukuran $1 \times 1 \mathrm{~m}$, jika jarak tanam $14 \mathrm{~cm} \times 30 \mathrm{~cm}$ seharusnya terdapat 24 lubang yang tertanami. Dari hasil tersebut persentase rata-rata jumlah lubang yang tertanami dengan sistem memanjang adalah $76,25 \%$ dan dengan sistem memendek adalah $75 \%$.

Tabel 5. Hasil Penanaman

\begin{tabular}{cccc}
\hline Sistem Petakan & $\begin{array}{c}\text { Jumlah } \\
\text { tertanam }\end{array}$ & $\begin{array}{c}\text { Keadaan } \\
\text { baik }\end{array}$ & $\begin{array}{c}\text { Kurang } \\
\text { baik }\end{array}$ \\
\hline Terkecil & 17 & 16 & 1 \\
Memanjang Sedang & 19 & 15 & 4 \\
Terbesar & 19 & 14 & 5 \\
\hline Terbesar & 16 & 13 & 3 \\
Memendek Sedang & 17 & 15 & 2 \\
Terbesar & 21 & 19 & 2 \\
\hline
\end{tabular}

Dengan demikian persentase ratarata posisi tertanam dalam keadaan baik dengan sistem memanjang adalah $62,50 \%$ dan persentase rata-rata posisi tertanam dalam keadaan kurang baik adalah $13,89 \%$. Sedangkan, persentase rata-rata posisi tertanam dalam keadaan baik dengan sistem memendek adalah 65,28\% dan persentase rata-rata posisi tertanam dalam keadaan kurang baik adalah 9,72\% .

Persentase tertanam dipengaruhi oleh keadaan lahan pada saat penanaman serta kepadatan penyemaian. Semakin banyak air saat penanaman, maka semakin banyak pula bibit yang tidak tertanam seperti tenggelam atau tidak bisa berdiri tegak. Sedangkan, kepadatan semaian yang tidak rata menyebabkan adanya kekosongan dalam baris tanam.

\section{c. Kebutuhan Bibit Tanam}

Benih disemai dengan cara penyemaian kering. Benih yang dibutuhkan untuk $600 \mathrm{~m}^{2}$ sebesar $8 \mathrm{~kg}$, sehingga untuk luasan $400 \mathrm{~m}^{2}$ dibutuhkan $5 \mathrm{~kg}$ benih. Luasan $700 \mathrm{~m}^{2}$ dibutuhkan 9 $\mathrm{kg}$ dan untuk luasan $1.000 \mathrm{~m}^{2}$ dibutuhkan benih sebanyak $13 \mathrm{~kg}$ (Sandra, 1995). Dalam penelitian ini, benih yang digunakan sebanyak $4 \mathrm{~kg}$. Hal ini dikarenakan dalam satu nampan terdapat 25 gram benih yang ditaburkan. Penyemaian dilakukan dengan melakukan perendaman terlebih dahulu, yaitu benih 
direndam dalam air selama 24 jam. Penyemaian dilakukan dengan menggunakan nampan yang telah disediakan oleh mesin yang berjumlah 150 nampan. Namun, dalam penelitian ini dibutuhkan 195 nampan sehingga untuk memenuhi ketersediaan jumlah nampan tersebut, dilakukan peminjaman nampan pada setiap kelompok tani yang memiliki atau yang menggunakan mesin rice transplanter.

Cara persemaian dapat dilihat pada Prosedur Penelitian. Sedangkan, kebutuhan semaian dengan sistem memanjang dan memendek dapat dilihat pada Tabel 6. Pada sistem memendek jumlah nampan yang dibutuhkan lebih sedikit dikarenakan pada saat penanaman lebih banyak yang tidak tertanam atau kosong yang disebabkan oleh pembelokan yang terlalu cepat dan lebar jarak yang terlalu sempit atau kecil.

Tabel 6. Kebutuhan Semaian Per Boks

\begin{tabular}{ccc}
\hline Sistem & $\begin{array}{c}\text { Petakan } \\
\left(\mathrm{m}^{2}\right)\end{array}$ & Boks (Nampan) \\
\hline \multirow{3}{*}{ Memanjang } & 400 & 7,98 \\
& 700 & 11,96 \\
& 1.000 & 19,96 \\
\hline \multirow{3}{*}{ Memendek } & 400 & 7,20 \\
& 700 & 10,8 \\
& 1.000 & 18,00 \\
\hline
\end{tabular}

\section{d. Jarak Tanam}

Jarak tanam sangat berpengaruh pada pertumbuhan tanaman padi. Bila tanaman terlalu rapat per-satuan luas, maka akan terjadi kompetisi dalam mendapatkan unsur hara dan sinar matahari. Sebaliknya, jika tanaman terlalu jarang persatuan luas maka tanaman lain seperti gulma akan cepat pertumbuhannya, karena sinar matahari dapat masuk ke tempat yang tidak tertanami padi (Sandra, 1995).

Jarak tanam rata-rata dengan sistem memanjang yang didapatkan adalah 15,3 $\mathrm{cm} \times 30 \mathrm{~cm}$ dan jarak tanam rata-rata dengan sistem memendek yang didapatkan adalah $15 \mathrm{~cm} \times 30 \mathrm{~cm}$. Penyetelan jarak tanam dalam lajur semula direncanakan $14 \mathrm{~cm}$ dan jarak tanam dalam baris $30 \mathrm{~cm}$, ternyata hasil yang diperoleh menyimpang. Hal ini disebabkan oleh keadaan olah lahan terlalu lembek dan banyak air sehingga pada saat penanaman, jari-jari tanam tergeser ke belakang mengakibatkan jarak tanam dalam lajur bertambah.

Tabel 7. Jarak Tanam

\begin{tabular}{cccc}
\hline Sistem & Petakan & $\begin{array}{c}\text { Jarak } \\
\text { Tanam } \\
(\text { Panjang }) \\
(\mathrm{cm})\end{array}$ & $\begin{array}{c}\text { Jarak } \\
\text { Tanam } \\
(\text { Lebar }) \\
(\mathrm{cm})\end{array}$ \\
\hline \multirow{3}{*}{ Memanjang } & Terkecil & 16 & 30 \\
& Sedang & 16 & 30 \\
& Terbesar & 14 & 30 \\
\hline \multirow{3}{*}{ Memendek } & Terkecil & 16 & 30 \\
& Sedang & 15 & 30 \\
& Terbesar & 14 & 30 \\
\hline
\end{tabular}

\section{e. Jumlah rumpun dan kedalaman tanam}

Banyaknya rumpun yang tertanam dalam satu lubang sangat berpengaruh pada pertumbuhan padi selanjutnya. Jumlah rumpun yang terlalu sedikit atau kurang akan mempengaruhi hasil akhir yang rendah, karena populasi tanaman berkurang. Sebaliknya, jika jumlah rumpun yang tertanam terlalu banyak, maka pertumbuhan tanaman akan terhambat yang disebabkan karena persaingan dalam penyerapan unsur hara lewat akar maupun perolehan sinar matahari yang semakin besar sehingga tanaman padi tumbuh tidak sempurna.

Demikian halnya dengan bibit yang ditanam bila terlalu dalam atau dangkal menyebabkan pertumbuhan tanaman kurang baik. Penanaman yang terlalu dalam dapat menyebabkan batang tanaman mudah membusuk (Sandra, 1995). Bibit yang tertanam terlalu dangkal berakibat sistem perakaran kurang kuat, sehingga tanaman mudah rebah. Hasil penanaman rata-rata yang direncanakan 
adalah 3 rumpun per lubang dengan kedalaman tanam $4,23 \mathrm{~cm}$.

Tabel 8. Jumlah Rumpun dan KedalamanTanam

\begin{tabular}{|c|c|c|c|}
\hline Sistem & Petakan & $\begin{array}{c}\text { Jumlah rumpun } \\
\text { per lubang }\end{array}$ & $\begin{array}{l}\text { Kedalaman } \\
\operatorname{tanam}(\mathrm{cm})\end{array}$ \\
\hline & Terkecil & 7 & 4 \\
\hline \multirow[t]{2}{*}{ Memanjang } & Sedang & 6 & 3 \\
\hline & Terbesar & 9 & 4 \\
\hline \multirow{3}{*}{ Memendek } & Terkecil & 8 & 4 \\
\hline & Sedang & 6 & 3 \\
\hline & Terbesar & 7 & 4 \\
\hline
\end{tabular}

Jumlah rumpun rata-rata per lubang tanam dengan sistem memanjang dan memendek adalah 7 rumpun per lubang dengan rata-rata kedalaman tanam 3,67 $\mathrm{cm}$. Jumlah rumpun per lubang tanam yang didapatkan menyimpang dari yang direncanakan. Hal ini disebabkan kepadatan semai yang terlalu padat sehingga pada saat penanaman jumlah rumpun yang ditanam berlebih dan mengakibatkan pemborosan benih. Sedangkan, kedalaman tanam sesuai dengan yang diharapkan.

\section{Performansi Mesin Rice transplanter a. Kapasitas Per Luasan}

Alat tanam tipe walking ini, pada luasan tanam rata-rata dengan sistem memanjang $700 \mathrm{~m}^{2}$ waktu yang diperlukan adalah 1083,4 detik (0,3 jam), sedangkan untuk luasan tanam rata-rata $700 \mathrm{~m}^{2}$ dengan menggunakan sistem memendek waktu yang diperlukan adalah 2238 detik (0,6 jam). Hal ini terlihat pada Tabel 9.

Tabel 9. Hasil Pengamatan Total Waktu Tanam

\begin{tabular}{cccccc}
\hline \multirow{2}{*}{ Sistem } & $\begin{array}{c}\text { Luas } \\
\left(\mathrm{m}^{2}\right)\end{array}$ & $\begin{array}{c}\text { Lintasan } \\
\text { Lintu } \\
\text { (Detik) }\end{array}$ & $\begin{array}{c}\text { Waktu } \\
\text { belok/ } \\
\text { Lintasan } \\
\text { (Detik) }\end{array}$ & $\begin{array}{c}\text { Total } \\
\text { waktu } \\
\text { tanam/ } \\
\text { Luasan } \\
\text { (Detik) }\end{array}$ & $\begin{array}{c}\text { Jumlah } \\
\text { Lintasar }\end{array}$ \\
\hline Memanjang 700 & 75,0 & 60,00 & 1089 & 11 \\
1.000 & 98,4 & 64,80 & 1569,6 & 13 \\
\hline 400 & 13,2 & 244,80 & 1793,4 & 33 \\
Memendek 700 & 18,0 & 258,00 & 2277,6 & 44 \\
1.000 & 22,2 & 307,20 & 2643 & 52 \\
\hline
\end{tabular}

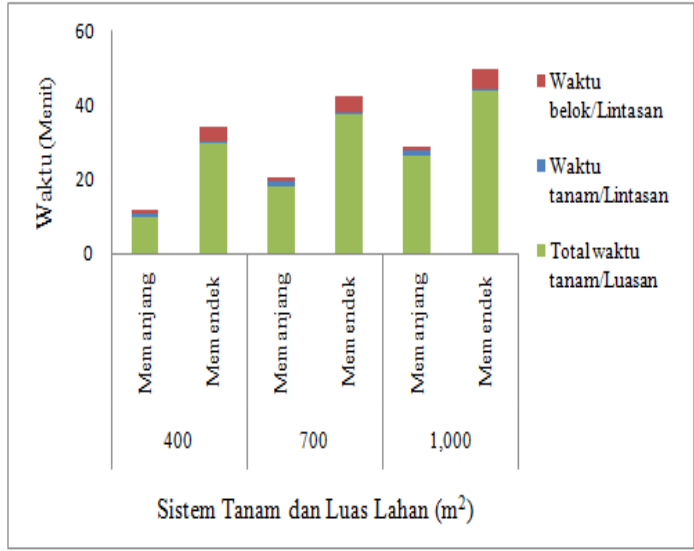

Gambar 3. Grafik Waktu Kerja Alat

Waktu belokan dan jumlah lintasan yang didapatkan dapat dilihat pada Tabel 9. Hasil waktu belokan yang berbeda disebabkan oleh jumlah lintasan yang didapatkan. Di mana hasil waktu belokan dan jumlah lintasan pada sistem memendek lebih besar dibandingkan dengan sistem memanjang. Hal ini disebabkan karena perbedaan sistem tanam dan luasan pada tiap petakan.

Waktu belokan pada luasan $400 \mathrm{~m}^{2}$ dengan sistem memanjang lebih besar dibandingkan dengan waktu tanamnya. Ini disebabkan oleh luasan yang berukuran lebih kecil dibandingkan dengan luasan lainnya. Waktu belokan pada sistem memendek lebih besar dibandingkan dengan waktu tanam, begitu juga sebaliknya pada sistem memanjang. Di mana pada sistem memanjang dengan luasan $700 \mathrm{~m}^{2}$ dan $1.000 \mathrm{~m}^{2}$ memiliki waktu belokan yang lebih sedikit dibandingkan dengan waktu tanamnya. Sehingga dikatakan bahwa sistem memanjang pada luasan yang besar lebih efisien dan efektif.

Waktu belokan sangat berpengaruh pada total waktu hasil tertanam. Sehingga semakin banyak belokan yang dilakukan, maka semakin besar total waktu hasil tertanam yang didapatkan. Begitu juga sebaliknya. Waktu tanam/lintasan dan waktu belokan/lintasan, hasil yang didapatkan tidak berbeda jauh. Ini dikarenakan operator yang digunakan sudah terbiasa dalam menggunakan mesin 
rice transplanter tipe walking ini. Operator tersebut berasal dari Desa Tanjung yang telah menggunakan mesin rice trasnplanter tipe walking sejak mesin tersebut diberikan oleh pemerintah, sehingga operator tidak mengalami kesulitan dalam mengoperasikan secara baik dan benar. Oleh sebab itu, kapasitas yang didapatkan untuk yang sistem memanjang hampir sama dengan kapasitas pabrik yang diinginkan.

Tabel 10. Kapasitas Kerja Mesin Sesuai Prosedur Pabrik 4-6,5 Jam

\begin{tabular}{|c|c|c|c|c|c|c|}
\hline \multirow{2}{*}{\multicolumn{2}{|c|}{ Petakan }} & & & \multirow[t]{3}{*}{$\begin{array}{l}\text { Kapasitas } \\
\text { (Ha/Jam) }\end{array}$} & \multicolumn{2}{|c|}{$\begin{array}{c}\text { Kapasitas yang didapatkan } \\
(\mathrm{Ha} / \mathrm{jam})\end{array}$} \\
\hline & & \multicolumn{2}{|c|}{ Waktu } & & & \\
\hline $\mathrm{Ha}$ & $\mathrm{m}^{2}$ & Jam & Menit & & Memanjang & Memendek \\
\hline 1 & 1.000 & 4 & 240 & 0,25 & 0,25 & 0,14 \\
\hline 0,04 & 400 & 0,16 & 9,60 & 0,25 & 0,20 & 0,08 \\
\hline 0,07 & 700 & 0,28 & 16,8 & 0,25 & 0,23 & 0,11 \\
\hline 0,10 & 1.000 & 0,4 & 24 & 0,25 & 0,25 & 0,14 \\
\hline
\end{tabular}

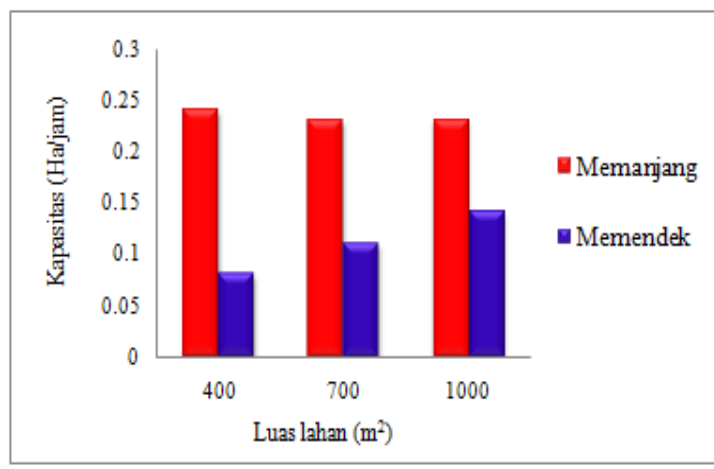

Gambar 4. Grafik Kapasitas Kerja Mesin

\section{b. Efisiensi Lapang}

Hasil perhitungan kapasitas lapang mesin berdasarkan data pengujian yang didapatkan dapat dilihat pada Gambar 5. Efisiensi lapang merupakan perbandingan antara kapasitas lapang efektif dengan kapasitaslapang teoritis, dinyatakan dalam persen. Waktu kerja efektif merupakan waktu yang dihabiskan mesin secara aktual untuk melakukanfungsi/kerjanya. Sedangkan, kapasitas lapang teoritis merupakan kecepatan penggarapan lahan yang akan diperoleh seandainya mesin tersebut melakukan kerja dengan memanfaatkan $100 \%$ waktunya, pada kecepatan maju teoritis dan memenuhi $100 \%$ lebar kerja teoritisnya (Sandra, 1995).

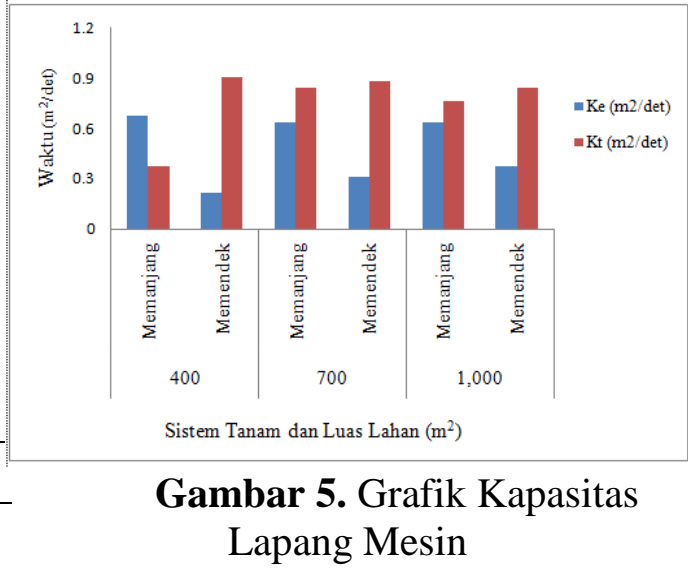

Kapasitas lapang teoritis yang diperoleh pada penelitian ini lebih besar dibandingkan dengan kapasitas lapang efektif. Hal ini dipengaruhi oleh kecepatan maju alat dan total waktu tanam. Jika kecepatan maju alat semakin besar dan total waktu tanam semakin banyak maka kapasitas lapang efektif akan semakin kecil dan kapasitas lapang teoritis akan semakin besar, begitu pula sebaliknya. Ketika kapasitas lapang teoritis lebih kecil dibandingkan dengan kapasitas lapang efektif maka efisiensi lapang yang didapatkan akan lebih dari $100 \%$ atau eror (Sandra, 1995).

Kapasitas lapang efektif untuk sistem memanjang nilainya lebih besar dibandingkan dengan kapasitas lapang efektif sistem memendek. Hal ini disebabkan oleh total waktu tanam yang semakin besar dan adanya perbedaan luasaan. Jika luasan semakin besar sedangkan total waktu tanam semakin kecil maka kapasitas lapang efektifnya semakin besar dan begitu pula sebaliknya. Kapasitas lapang teoritis yang diperoleh untuk sistem memanjang memiliki nilai yang tidak berbeda jauh dengan kapasitas lapang teoritis pada sistem memendek. Hal ini disebabkan karena kecepatan maju 
alat pada sistem memanjang dan memendek hampir sama.

Dari Gambar 5, dapat dilihat bahwa, kapasitas lapang teoritis pada sistem memanjang dengan luasan terbesar, yakni $1.000 \mathrm{~m}^{2}$ memiliki nilai yang lebih kecil dibandingkan dengan luasan lainnya. Bahkan nilai pada luasan tersebut lebih kecil dibandingkan dengan luasan pada sistem memendek. Hal ini disebabkan oleh pengaruh kecepatan maju alat yang berbeda. Kecepatan maju alat pada luasan $1.000 \mathrm{~m}^{2}$ dengan menggunakan sistem memanjang memiliki nilai kecepatan maju alat yang lebih sedikit dibandingkan dengan luasan lainnya.

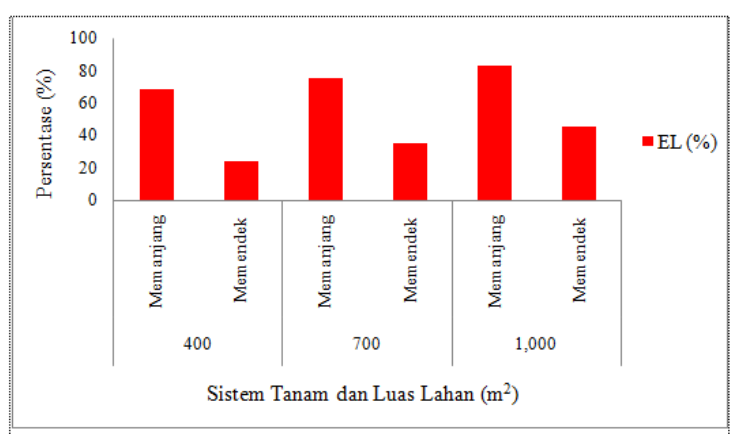

Gambar 6. Grafik Efisiensi Lapang Mesin

Dari hasil tersebut diperoleh bahwa perbedaan luasan menyebabkan efisiensi lapang yang didapatkan juga berbeda. Suatu mesin dapat dikatakan efisien apabila memiliki nilai di atas 50\% (Anonim ${ }^{1}$, 2015). Efisiensi lapang alat dengan luasan $400 \mathrm{~m}^{2}$ pada sistem memanjang didapatkan hasil sebesar $68 \%$, sedangkan luasan $400 \mathrm{~m}^{2}$ pada sistem memendek sebesar 24\%. Hal ini disebabkan karena kondisi tanah dan waktu belokan. Pada sistem memanjang, total waktu tanam yang didapatkan lebih sedikit karena tidak terlalu banyak waktu belokan dan kondisi tanah yang tidak terlalu banyak kotoran yang dapat mengganggu kecepatan maju alat. Pada efisiensi lapang untuk luasan $700 \mathrm{~m}^{2}$ dan $1.000 \mathrm{~m}^{2}$ mengalami hal serupa. Oleh sebab itu, dari segi luasan efisiensi lapang yang memiliki hasil yang baik terlihat pada luasan $1.000 \mathrm{~m}^{2}$. Hal ini terlihat pada Gambar 6.

Perbedaan cara penanaman menyebabkan efisiensi lapang berbeda. Efisiensi lapang alat dengan sistem memanjang sebesar $68 \%$ untuk petakan terkecil, $75 \%$ untuk petakan sedang dan $83 \%$ untuk petakan terbesar. Sedangkan, nilai efisiensi lapang alat dengan sistem memendek memiliki nilai sebesar $24 \%$ untuk petakan terkecil, $35 \%$ untuk petakan sedang dan $45 \%$ untuk petakan terbesar. Hal ini disebabkan karena pengaruh total waktu tanam dan kecepatan maju alat yang dihasilkan berbeda.

Efisiensi lapang yang diperoleh sangat rendah untuk sistem memendek sehingga dapat dikatakan sistem memendek tidak efisien untuk digunakan. Dari hasil efisiensi lapang yang telah didapatkan, maka sebaiknya pemerintah melakukan peninjauan ulang kembali dalam membantu kegiatan masyarakat khususnya dibidang pertanian, seperti pemberian mesin rice transplanter. Peninjauan ulang kembali tersebut dapat dilakukan dengan meninjau tiap daerah yang akan diberikan mesin rice transplanter, baik dari segi topografi maupun geografisnya. Hal ini dikarenakan agar pemberian yang dilakukan dapat tepat sasaran guna meningkatkan produktivitas kerja petani.

\section{KESIMPULAN \& SARAN}

\section{Kesimpulan}

Berdasarkan hasil penelitian dan pembahasan yang telah dilakukan, maka dapat disimpulkan sebagai berikut:

1. Penanaman dengan luasan yang berbeda, menyebabkan efisiensi lapang juga berbeda. Sehingga dari segi luasan untuk efisiensi yang baik dihasilkan pada luasan yang luas atau terbesar, yakni $1.000 \mathrm{~m}^{2}$ dengan hasil $83 \%$, yang sedang $700 \mathrm{~m}^{2}$ sebesar $75 \%$ dan yang terkecil $400 \mathrm{~m}^{2}$ sebesar $68 \%$.

2. Efisiensi lapang yang diperoleh sangat rendah untuk yang sistem memendek, 
yakni di bawah 50\% sehingga dikatakan sistem memendek tidak efisien untuk digunakan, hal ini disebabkan oleh waktu belokan yang banyak. Di mana efisiensi lapang untuk luasan terbesar $1.000 \mathrm{~m}^{2}$ didapatkan hasil $45 \%$, yang sedang $700 \mathrm{~m}^{2}$ sebesar $35 \%$ dan yang terkecil $400 \mathrm{~m}^{2}$ sebesar $24 \%$.

3. Kapasitas tanam yang didapatkan untuk sistem memanjang sudah sesuai dengan standar kapasitas pabrik yang diinginkan, sedangkan sistem memendek tidak sesuai.

4. Waktu belokan sangat berpengaruh pada total waktu hasil tertanam. Sehingga semakin banyak belokan yang dilakukan, maka semakin besar total waktu hasil tertanam yang didapatkan. Begitu juga sebaliknya.

\section{Saran}

Perlu dilakukan penelitian selanjutnya denganalat semai (rice transplanter) dengan tipe yang berbeda dan dalam hal pengaturan lubang penjatuhan benih dan perbedaan penggunaan operator.

\section{DAFTAR PUSTAKA}

Anonim $^{1}$. 2015. Penggunaan Lahan di Kabupaten Lombok Utara. Badan Pusat Statistik Kabupaten Lombok Utara. Kabupaten Lombok Utara.

Anonim $^{2}$. 2015. Statistik Daerah Kabupaten Lombok Utara 2015. Badan Pusat Statistik. Kabupaten Lombok Utara. NTB.

Sandra, Nevi. 1995. Uji Performansi Alat Tanam Padi (Rice transplanter) Tipe Riding Pada Berbagai Pengolahan Tanah di Areal Infrastruktur Leuwikopo Darmaga, Bogor. Skripsi. Institut Pertanian Bogor. Bogor.

Siregar, Hadrian. 2009. Rancangan Percobaan Teori dan Aplikasi.PT. Raja Grapindo.

Kohnosuke, Tsuga. 1992. Rice transplanter. Institute of Agricultural Machinery. Biooriented Technology Research Advancement Institution Planting System Laboratory. Japan. 